Sains Malaysiana 50(6)(2021): 1673-1683

http://doi.org/10.17576/jsm-2021-5006-14

\title{
Kesan Prarawatan dan Masa Hidrolisis Enzim untuk Penghasilan Oligosakarida daripada Serabut Mesokarpa Buah Kelapa Sawit
}

(Effect of Pretreatment and Enzymatic Hydrolysis for Oligosaccharide Production from Oil Palm Mesocarp Fibre)

\section{Nurul Hanisah Mohd, Rizafizah Othaman, Mukram Mohamed Mackeen \& Mohamad Yusof Maskat*}

\section{ABSTRAK}

Dalam kajian ini, serabut mesokarpa buah kelapa sawit (SM) telah ditukar menjadi oligosakarida sebagai produk nilai tambah. Objektif kajian ini adalah untuk menentukan kesan prarawatan dan masa hidrolisis untuk penghasilan oligosakarida dengan menggunakan kompleks enzim komersial Celluclast (1.5 L). Prarawatan dengan larutan 5\% $(\mathrm{v} / \mathrm{v})$ natrium hidroksida $(\mathrm{NaOH})$ dan $5 \%(\mathrm{v} / \mathrm{v})$ larutan asid asetik $\left(\mathrm{CH}_{3} \mathrm{COOH}\right)$ dilakukan sebelum hidrolisis enzim. Prarawatan menggunakan kepekatan 5, 10 dan 15\% (v/v) larutan $\mathrm{NaOH}$ dijalankan dalam autoklaf pada $120{ }^{\circ} \mathrm{C}$ selama 30 min. Hidrolisis SM prarawatan telah dijalankan pada masa hidrolisis 0, 3, 6 dan 24 jam. Hasil hidrolisis enzim membuktikan bahawa prarawatan alkali SM dengan 5\% NaOH menghasilkan jumlah gula penurun yang lebih tinggi berbanding dengan SM mentah dan SM prarawatan menggunakan 5\% $\mathrm{CH}_{3} \mathrm{COOH}$ dengan masing-masing menghasilkan $351.94 \mathrm{mg} / \mathrm{g}$ berbanding 181.44 dan $183.15 \mathrm{mg} / \mathrm{g}$ jumlah gula penurun per jisim biojisim. Pertambahan jumlah gula penurun untuk prarawatan alkali disebabkan penyingkiran bahagian lignin dan hemiselulosa dalam SM. Peningkatan kepekatan NaOH menghasilkan peratus sakarifikasi yang lebih tinggi. Hidrolisis SM prarawatan selama 3 hingga 24 jam telah menghasilkan oligosakarida dengan bilangan unit glukosa 2, 3 dan 4. Tiada perbezaan unit glukosa diperhatikan apabila masa hidrolisis ditingkatkan daripada 3 hingga 24 jam. Kajian ini menunjukkan keupayaan penghasilan oligosakarida daripada SM dengan memanipulasi masa hidrolisis.

Kata kunci: Masa hidrolisis; oligosakarida; prarawatan alkali; sakarifikasi lignoselulosa; serabut mesokarpa kelapa sawit

\section{ABSTRACT}

In this study, oil palm mesocarp fibre (SM) was converted into oligosaccharides as a value-added product. The objective of this study was to determine the effect of pretreatment and hydrolysis time for oligosaccharide production using a commercial Celluclast (1.5 L) enzyme complex. Pretreatment with 5\% (v/v) sodium hydroxide (NaOH) and $5 \%$ $(v / v)$ acetic acid solution $\left(\mathrm{CH}_{3} \mathrm{COOH}\right)$ was performed before enzyme hydrolysis. Pretreatment using concentrations of 5,10 and $15 \%(\mathrm{v} / \mathrm{v}) \mathrm{NaOH}$ solution was carried out in an autoclave at $120^{\circ} \mathrm{C}$ for 30 min. Hydrolysis of the alkaline pretreated SM was performed at 0, 3, 6, and $24 \mathrm{~h}$. Enzymatic hydrolysis results indicated that pretreatment of SM with $5 \% \mathrm{NaOH}$ produced a higher amount of reducing sugar compared to raw SM and 5\% $\mathrm{CH}_{3} \mathrm{COOH}$ SM pretreatment, producing $351.94 \mathrm{mg} / \mathrm{g}$ compared to 181.44 and $183.15 \mathrm{mg} / \mathrm{g}$ amount of reducing sugar per mass of biomass, respectively. The increased amount of sugars for alkali pretreatment was due to the removal of lignin and hemicellulose portions in SM. Increased NaOH concentration resulted in a higher percentage of saccharification. Hydrolysis of pretreated SM for 3 to 24 h produced oligosaccharides with 2, 3 and 4 glucose units. No differences in the number of glucose units were observed when hydrolysis time was increased from 3 to $24 \mathrm{~h}$. This study demonstrated the ability of oligosaccharide production from SM by manipulating hydrolysis time.

Keywords: Alkaline pretreatment; hydrolysis time; lignocellulosic saccharification; oil palm mesocarp fibre; oligosaccharides

\section{PENDAHULUAN}

Pada ketika ini, peningkatan pemahaman mengenai peranan penting yang dimainkan oleh mikroorganisma dalam mengekalkan kesihatan usus telah mengakibatkan permintaan yang meningkat terhadap penggunaan bahan pre dan probiotik. Bahan-bahan ini bertindak melalui dua pendekatan berbeza. Bahan yang terdiri daripada mikroorganisma hidup dipanggil sebagai probiotik. Bahan 
yang terdiri daripada sebatian bukan mikroorganisma yang secara selektif merangsang pertumbuhan dan/atau aktiviti satu atau beberapa bakteria bermanfaat dalam kolon dirujuk sebagai prebiotik (Gibson et al. 2017; Peerakietkhajorn et al. 2020). Pada masa ini, sebilangan kecil sebatian telah terbukti mempunyai kesan prebiotik dalam usus manusia. Sebatian prebiotik biasanya terdiri daripada oligosakarida. Sebatian ini termasuk frukto oligosakarida (FOS) (Hustoft et al. 2016), galakto oligosakarida (GOS) (Wilson \& Whelan 2017) dan gluko oligosakarida (Moller et al. 2014). Beberapa pendekatan telah dibuat untuk menghasilkan ingredien prebiotik yang baru. Ini termasuk ingredien prebiotik daripada gam flaxseed (Liang et al. 2017), pektin kulit buah sitrus (Zhang et al. 2018) dan daripada pucuk anggur (Davila et al. 2019).

Mesokarpa buah kelapa sawit adalah lapisan berserat yang menyelaputi tempurung buah kelapa sawit. Semasa penghasilan minyak kelapa sawit, mesokarpa dibuang sebagai sisa selepas pengekstrakan minyak. Ia adalah biojisimlignoselulosa kompleks yang terdiri daripada selulosa, hemiselulosa dan lignin. Satu tan buah kelapa sawit berupaya menghasilkan kira-kira 0.12 tan mesokarpa (Zakaria et al. 2014). Kebiasaannya, mesokarpa kelapa sawit digunakan sebagai baja atau bahan api untuk menghasilkan tenaga untuk dandang stim yang merupakan penggunaan bernilai rendah (Iberahim et al. 2013). Penghasilan mesokarpa kelapa sawit dijangka meningkat dengan ketara pada masa hadapan melebihi jumlah yang diperlukan oleh kapasiti dandang kilang yang terhad (Warid et al. 2016). Oleh itu, penggunaan nilai baru dan nilai tambah mesokarpa kelapa sawit diperlukan pada masa akan datang untuk menampung peningkatan pengeluarannya. Penukaran mesokarpa buah kelapa sawit kepada bahan-bahan berfungsi seperti serat larut yang terdiri daripada oligosakarida, akan dapat menghasilkan produk yang bernilai lebih tinggi dan peningkatan keuntungan bagi industri kelapa sawit (Pasma et al. 2018). Di samping itu, dapat mengelakkan industri kelapa sawit daripada kemungkinan tuduhan amalan tidak mesra alam.

Oligosakarida adalah karbohidrat dengan darjah pempolimeran (dP) rendah iaitu 3-10 unit gula (Karnaouri et al. 2019). Oligosakarida juga wujud secara semula jadi dalam kelapa sawit di beberapa bahagian pokok yang berbeza. Pelbagai usaha untuk mengekstrak oligosakarida ini telah dilakukan dan dikaji kesannya terhadap prebiotik. Jahromi et al. (2016) telah mengekstrak dan mencirikan oligosakarida daripada isirong buah kelapa sawit sebagai prebiotik. Aktiviti prebiotik mannan oligosakarida daripada isirong buah kelapa sawit juga telah ditentukan (Kalidas et al. 2017; Nurhayati et al.
2018). Walau bagaimanapun, kuantiti pengeluaran oligosakarida ini adalah terhad kerana pengeluarannya adalah melalui proses pengekstrakan sebatian prebiotik sedia ada dan bukan dihasilkan menggunakan proses tertentu daripada sumber yang banyak. Oleh itu, kemampuan untuk menukar selulosa daripada mesokarpa buah kelapa sawit yang boleh didapati dengan banyaknya kepada oligosakarida prebiotik boleh menghasilkan produk yang berdaya maju dari segi ekonomi dan komersial.

Penukaran bahan lignoselulosik kepada oligosakarida melalui hidrolisis enzim adalah satu kaedah yang bersifat mesra alam. Terdapat banyak kajian yang telah dijalankan terhadap bahan lignoselulosa termasuk mesokarpa buah kelapa sawit bagi menukarkan selulosa kepada monomernya iaitu glukosa. Proses penghasilan glukosa daripada bahan lignoselulosa ini melibatkan langkah sakarifikasi yang memotong ikatan glikosidik menggunakan enzim selulase. Namun, bahan lignoselulosik tidak boleh disakarifikasi oleh enzim selulase untuk penghasilan gula kecuali ia diproses melalui prarawatan mekanikal, fizikal dan kimia untuk menyingkirkan struktur kompleks lignin yang menjadi penghalang terhadap hidrolisis enzim, mengurangkan penghabluran dan darjah pempolimeran selulosa, meningkatkan luas kawasan permukaan substrat untuk tindakan enzim, serta meningkatkan kerentanan substrat kepada enzim (Alrumman 2016; Hassan et al. 2013; Pasma et al. 2019). Malah, prarawatan dapat mengganggu struktur polisakarida iaitu selulosa yang bertaut silang yang menjadikannya penghalang kepada proses hidrolisis oleh enzim untuk ditukarkan kepada gula (Ali et al. 2015).

Antara kaedah prarawatan yang biasa digunakan sebelum sakarifikasi bahan lignoselulosa adalah prarawatan menggunakan asid dan alkali. Penggunaan asid mineral yang kuat dalam proses prarawatan biojisim seperti asid sulfurik telah terbukti dengan baik dalam beberapa dekad kebelakangan ini. Prarawatan asid sulfurik cair yang dicampurkan dengan biojisim dapat menghidrolisiskan hemiselulosa menjadi xilosa serta gula lain dan kemudian terus memecahkan xilosa kepada furfural. Namun begitu, proses prarawatan menggunakan asid sulfurik ini juga menyebabkan pemecahan struktur selulosa kepada glukosa sebelum proses asid hidrolisis berlaku. Lignin dalam biojisim lignoselulosa memerlukan kaedah prarawatan yang cukup kuat untuk pembebasan gula larut fermentasi tetapi persekitaran berasid boleh menyebabkan kehilangan gula yang difermentasi dalam bentuk furfurals dan 5-hidroksimetil furfural. Oleh itu, penggunaan asid asetik $\left(\mathrm{CH}_{3} \mathrm{COOH}\right)$ dalam kaedah prarawatan telah diseragamkan untuk meningkatkan bio ketersediaan gula difermentasi selepas proses prarawatan (Saha et al. 2016). Kajian lepas 
melaporkan, dalam beberapa kes, langkah hidrolisis enzim didapati terhindar daripada berlaku kerana asid itu sendiri menghidrolisis biojisim menjadi gula larut fermentasi.

Berbeza dengan prarawatan asid, kaedah prarawatan alkali secara umum boleh dilakukan pada suhu dan tekanan ambien. Reagen alkali yang paling biasa digunakan adalah terbitan hidroksil daripada garam natrium, kalium, kalsium dan amonium. Antara terbitan hidroksil ini, didapati natrium hidroksida $(\mathrm{NaOH})$ adalah paling berkesan. Hal ini kerana, reagen alkali ini mendegradasikan rantai sisi ester dan glikosida yang membawa kepada pengubahsuaian struktur lignin, pembengkakan selulosa, penyahhabluran selulosa dan pemecahan hemiselulosa yang menjurus kepada peningkatan luas permukaan bahagian selulosa dan lebih mudah diakses oleh enzim (Kumar \& Sharma 2017; Ren et al. 2019). Contohya dalam kajian Dong et al. (2019), 2\% $\mathrm{NaOH}$ menunjukkan kecekapan enzim hidrolisis tertinggi $(86.44 \%)$ diikuti oleh $2 \%$ asid sulfurik $(75.07 \%)$ dan $10 \%$ hidrogen peroksida (66.6\%). Manakala, prarawatan biojisim poplar, swicthgrass, tongkol jagung dan jerami padi dilaporkan berkesan dalam prarawatan $\mathrm{NaOH}$ daripada asid sulfurik cair dari segi penyah-lignifikasi dan hasil gula (Ioelovich \& Morag 2012; Wu et al. 2017). Prarawatan alkali dengan $\mathrm{NaOH}$ adalah pilihan yang murah dan kos rendah untuk mengubah struktur lignoselulosa sebelum hidrolisis dan fermentasi karbohidrat. Ia boleh dilakukan menggunakan pelbagai keadaan operasi (Modenbach \& Nokes 2012). Sebagai contoh, masa tindak balas boleh dipendekkan kepada beberapa minit atau jam atau hari, pada suhu sekitar $150^{\circ} \mathrm{C}$ (Modenbach \& Nokes 2014). Menggunakan $\mathrm{NaOH}$ untuk prarawatan juga mempunyai faedah tambahan kerana reagen alkali kurang kaustik daripada asid cair (Aftab et al. 2019). Ia juga dapat dikumpul kembali dan dikitar semula reagen alkali serta berpotensi mengurangkan kos yang berkaitan dengan prarawatan (Modenbach \& Nokes 2014; Wicaksono et al. 2017). Oleh kerana masih belum ada kajian yang membandingkan kesan prarawatan asid dan alkali untuk penghasilan oligosakarida daripada mesokarpa buah kelapa sawit, ia dijalankan di dalam kajian ini.

Kajian lepas menyatakan penghasilan glukosa daripada bahan lignoselulosa ini melibatkan langkah sakarifikasi yang memotong ikatan glikosidik menggunakan enzim selulase. Proses sakarifikasi ini dipengaruhi oleh beberapa faktor termasuk masa hidrolisis. Masa hidrolisis akan mempengaruhi darjah pemotongan ikatan glikosidik di antara monomer. Justeru, adalah mungkin masa hidrolisis ini dimanipulasi untuk menghasilkan oligosakarida melalui proses sakarifikasi menggunakan enzim selulase daripada mesokarpa buah kelapa sawit.
Dengan itu, kajian ini dijalankan untuk mengkaji kesan prarawatan asid rendah dan alkali tinggi serta kesan masa hidrolisis terhadap penghasilan oligosakarida daripada mesokarpa buah kelapa sawit.

\section{BAHAN DAN KAEDAH}

\section{BAHAN KIMIA}

Serabut mesokarpa buah kelapa sawit (SM) diperoleh daripada Dengkil Palm Oil Mill Sdn. Bhd. Natrium hidroksida $(\mathrm{NaOH})$, asid asetik glasial $\left(\mathrm{CH}_{3} \mathrm{COOH}\right)$, natrium asetat kontang $\left(\mathrm{C}_{2} \mathrm{H}_{3} \mathrm{NaO}_{2}\right)$, dibekalkan oleh Systerm, Malaysia, manakala larutan penimbal asetat (pH 4.0), dextran, asetat ammnonia, 2-antralamida (2-AB), sianoborohidrid, Celluclast (1.5 L) daripada Trichoderma reesei (>700 units/g) diperoleh daripada Sigma Aldrich Co. (St. Louis MO, USA) mempunyai campuran eksoselulase, endoselulase dan $\beta$-glukosidase, manakala asetonitril diperoleh daripada Merck \& Co. (USA).

\section{PRARAWATAN DAN HIDROLISIS ENZIM SERABUT MESOKARPA BUAH KELAPA SAWIT (SM)}

Serabut mesokarpa buah kelapa sawit (SM) dalam bentuk helaian longgar diperoleh daripada Dengkil Palm Oil Mill Sdn. Bhd., Malaysia. Serabut dibasuh menggunakan air suling untuk menyingkirkan sisa minyak dan kotoran, seterusnya dikeringkan di dalam relau pada suhu $80{ }^{\circ} \mathrm{C}$ untuk semalaman sebelum dikisar menggunakan mesin pengisar untuk mendapatkan saiz maksimum $0.25 \mathrm{~mm}$ sebelum menjalankan kaedah prarawatan.

Pada awalnya, perbandingan kaedah prarawatan asid dan alkali telah dijalankan mengikut kaedah Hassan et al. (2013) dengan sedikit pengubahsuaian. Prarawatan dijalankan di dalam autoklaf (HV-50 Hirayama, Jepun) dengan menggunakan $5 \%$ larutan $\mathrm{CH}_{3} \mathrm{COOH}$ dan larutan natrium hidroksida $(\mathrm{NaOH})$. Prarawatan hidrotermal SMKS dengan 5\% larutan $\mathrm{CH}_{3} \mathrm{COOH}$ dan $5 \% \mathrm{NaOH}$ dipilih adalah berdasarkan kajian Hassan et al. (2013) mendapati prarawatan serabut tandan kosong kelapa sawit (STKKS) dengan (wap $+5 \%$ larutan $\mathrm{CH}_{3} \mathrm{COOH}$ ) menyebabkan berlaku perubahan paling ketara pada permukaan biojisim selepas dilakukan prarawatan hidrotermal hasil penyingkiran sebahagian lignin dan hemiselulosa. Prarawatan dalam kajian ini dilakukan pada suhu $120^{\circ} \mathrm{C}$ dengan bertekanan wap selama 30 min dengan nisbah biojisim kepada cecair sebanyak 1:10 (w/v\%) (Iberahim et al. 2013; Kumar \& Sharma 2017; Pasma et al. 2013). Penggunaan suhu $120^{\circ} \mathrm{C}$ adalah berdasarkan 
kajian Pasma et al. (2013) dengan proses prarawatan autohidrolisis dalam alat autoklaf telah dijalankan pada suhu $120^{\circ} \mathrm{C}$ untuk tempoh masa 1-2 jam. Malah, menurut Kumar dan Sharma (2017), dua jenis prarawatan asid diperkembangkan iaitu penggunaan suhu tinggi ( $>180$ ${ }^{\circ} \mathrm{C}$ ) untuk tempoh masa pendek iaitu 1-5 min dan suhu rendah $\left(<120{ }^{\circ} \mathrm{C}\right)$ untuk tempoh masa lama iaitu 30-90 min. Namun dalam kajian ini, masa 30 min mencukupi untuk merubah struktur hemiselulosa dan selulosa untuk tindakan enzim hidrolisis berdasarkan keputusan yang diperoleh sebelum ini. Kemudian, prarawatan dengan 5, 10 dan $15 \%(\mathrm{w} / \mathrm{v})$ telah dijalankan dengan larutan $\mathrm{NaOH}$. Serabut yang telah dirawat, dituras dan dibasuh dengan air suling sehingga $\mathrm{pH}$ neutral. Serabut pada $\mathrm{pH}$ neutral, dikeringkan di dalam relau pada $75{ }^{\circ} \mathrm{C}$ selama 12 jam sebelum disimpan dalam bekas tertutup pada suhu bilik untuk kegunaan selanjutnya.

Kaedah hidrolisis enzim dijalankan mengikut kajian lepas dengan sedikit pengubahsuaian (Pasma et al. 2013). Hidrolisis enzim ke atas serabut terprarawat telah dijalankan di dalam kelalang Erlenmeyer $250 \mathrm{~mL}$ pada suhu $50{ }^{\circ} \mathrm{C}$ dan kelajuan $120 \mathrm{rpm}$ menggunakan inkubator penggoncang. Dalam tindak balas hidrolisis, 5\% (w/v) serabut ditambah ke dalam $9 \mathrm{~mL}$ larutan penimbal asetat, (0.005 M, pH 4.8) dan diinkubasi selama 2 jam $\left(50{ }^{\circ} \mathrm{C}\right.$, $120 \mathrm{rpm})$. Seterusnya, $1 \%(\mathrm{v} / \mathrm{v})$ enzim Celluclast $(1.5 \mathrm{~L})$ (Aktiviti: $700 \mathrm{EGU} / \mathrm{g}$ ) ditambah dan dihidrolisis selama 0, 3, 6 dan 24 jam. Selepas hidrolisis, sampel dipanaskan dalam air rendaman pada suhu $80-90{ }^{\circ} \mathrm{C}$ selama $20 \mathrm{~min}$ untuk menyahaktifkan enzim dan diemparkan pada $4000 \mathrm{rpm}$ selama $15 \mathrm{~min}$ untuk pengasingan hidrolisat. Hidrolisat disimpan pada suhu $4-8^{\circ} \mathrm{C}$ sehingga dianalisis.

\section{PENENTUAN JUMLAH GULA PENURUN}

Jumlah gula penurun yang dihasilkan oleh hidrolisis enzim ditentukan dengan kaedah asid dinitrosalisailik (DNS) mengikut kaedah Alrumman (2016) dan Ghose (1987) dengan sedikit pengubahsuaian. Sampel (1.0 mL) dicampur dengan $3 \mathrm{~mL}$ reagen DNS dalam tabung uji. Kemudian campuran dipanaskan dalam air rendaman pada $100{ }^{\circ} \mathrm{C}$ selama 5 min sehingga warna jingga kekuningan bertukar kepada perang kemerahan. Selepas itu, sampel disejukkan pada suhu bilik dan penyerapan diukur pada $540 \mathrm{~nm}$ menggunakan UV-spektofotometer. Jumlah gula penurun dihitung dengan menggunakan lengkuk glukosa piawai dalam unit $\mathrm{mg} / \mathrm{mL}$. Peratusan sakarifikasi dihitung menggunakan persamaan Mandels dan Sternberg (1976) seperti berikut:

$$
\% \text { Sakarifikasi }=\frac{\text { Gula penurun }(\mathrm{mg} / \mathrm{mL}) \times 0.9 \times 100 \%}{\text { Kepekatan awal substrat }(\mathrm{mg} / \mathrm{mL})}
$$

Faktor 0.90 digunakan untuk menukarkan polisakarida kepada monosakarida untuk anggaran pengambilan air semasa hidrolisis.

Penentuan oligosakarida daripada serabut tanpa dan dengan prarawatan ditentukan menggunakan kromatografi cecair prestasi tinggi (KCPT) pam Waters 600 dan pengsampelan automatik Waters 2707 dengan pengesan pendarfluor model Waters 2745. Dekstran digunakan sebagai piawai dan kesemua sampel dilabel dengan 2-aminobenzamida (2-AB) menggunakan kolum amida XBridge $(4.6 \times 250 \mathrm{~mm}$, saiz partikel 3.5 $\mu \mathrm{m})$ dengan sistem elusi kecerunan gabungan pelarut ammonium asetat ( $\mathrm{pH} 3.5)$ dan asetonitril seperti kaedah yang dilaporkan dalam Jalaludin et al. (2017) dan Woon et al. (2016). Sebanyak $10 \mu \mathrm{L}$ sampel hidrolisat disuntik untuk penentuan oligosakarida yang dijalankan pada keadaan jarak gelombang $360 \mathrm{~nm}$ (pengujaan) dan 426 $\mathrm{nm}$ (pancaran) pengesan pendafluor.

\section{ANALISA STATISTIK}

Kesemua uji kaji telah diulang sebanyak tiga kali. Manakala, ujian statistik bagi data gula penurun telah dijalankan menggunakan analisis ANOVA sehala melalui perisian SPSS. Data gula penurun bagi sampel SM sebelum dan selepas parawatan telah dibandingkan menggunakan ujian Tukey HSD.

\section{HASIL DAN PERBINCANGAN}

\section{PERBANDINGAN KAEDAH PRARAWATAN BERBEZA}

Prarawatan bahan lignoselulosik SMKS telah dijalankan untuk meningkatkan akses selulosa oleh tindakan hidrolisis enzim. Rajah 1 menunjukkan kandungan gula penurun selepas proses hidrolisis enzim bagi SM mentah dan prarawatan dengan $5 \%(\mathrm{v} / \mathrm{v}) \mathrm{CH}_{3} \mathrm{COOH}$ dan $\mathrm{NaOH}$. Berdasarkan hasilnya, kandungan gula penurun SM prarawatan dengan $5 \%(\mathrm{v} / \mathrm{v})$ larutan $\mathrm{NaOH}$ yang diautoklaf pada suhu $120{ }^{\circ} \mathrm{C}$ selama $30 \mathrm{~min}$, mempamerkan peningkatan sebanyak dua kali=ganda $(\mathrm{p}<0.05)$ iaitu hampir $20 \mathrm{mg} / \mathrm{mL}$ berbanding larutan asid dan SM mentah. Peningkatan kandungan gula penurun dalam SM prarawatan 5\% (v/v) $\mathrm{NaOH}$ ini menunjukkan kesan signifikan penyingkiran sebahagian lignin dan hemiselulosa daripada zarah SMKS semasa proses prarawatan telah berlaku. Penyingkiran ini berlaku disebabkan oleh proses prarawatan hidrotermal dengan kehadiran alkali dalam akeus lignoselulosik meningkatkan gangguan pada bahagian lignin dan hemiselulosa. Malah, menurut Ali et al. (2015), kehadiran 
$\mathrm{NaOH}$ meningkatkan sifat poli-ion lignoselulosa yang disusun berkait dengan penyebaran ion natrium ke dalam lignoselulosa yang juga bertindak sebagai penukaran kepada ion karboksilat.

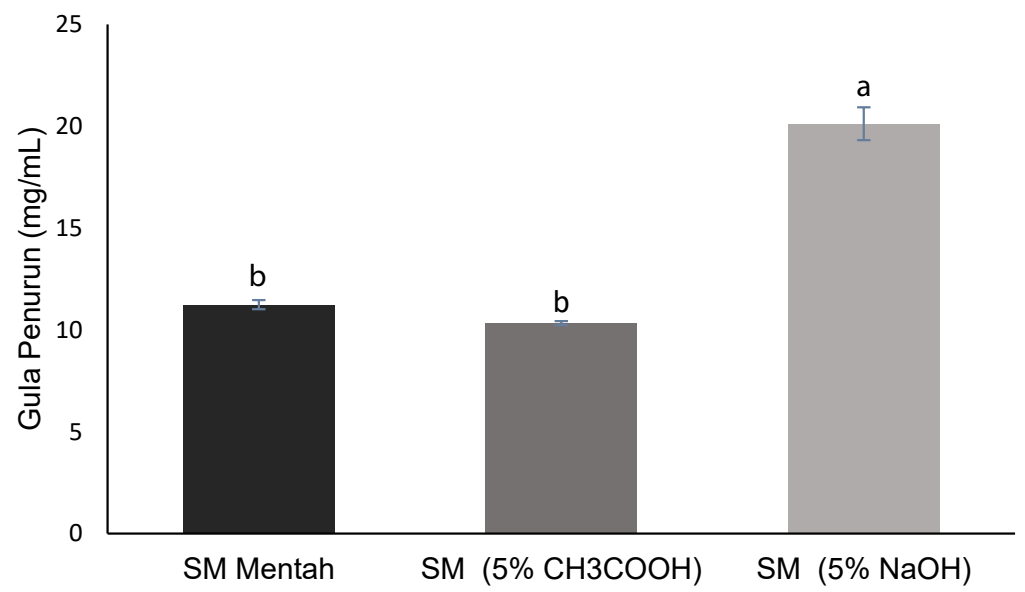

RAJAH 1. Kandungan gula penurun di dalam serabut mesokarpa buah kelapa sawit (SM) yang diberi prarawatan berbeza

${ }^{a-b}$ : Min dengan huruf yang berbeza adalah berbeza secara signifikan $(\mathrm{p}<0.05)$

Sifat poli-ion ini menggalakkan pembengkakan berbanding dengan prarawatan $\mathrm{NaOH}$ diikuti dengan cucian asid dengan ion natrium digantikan oleh proton. Justeru, $\mathrm{NaOH}$ dalam proses prarawatan bertindak sebagai agen pembengkakan membuka struktur selulosa, mewujudkan banyak lompang kecil dan penguraian selulosa, dengan itu meningkatkan akses selulosa kepada hidrolisis (Ali et al. 2015; Kumar \& Sharma 2017). Tambahan pula, menurut Modenbach dan Nokes (2014), ikatan ester antara asid ferulik dalam struktur lignin dan karbohidrat sangat mudah terdedah kepada degradasi alkali, kerana ion hidroksida meningkatkan kadar tindak balas rawatan. Hal ini disokong dengan jumlah gula penurun yang dihasilkan per gram substrat seperti dipaparkan dalam Rajah 2, menunjukkan SM yang dirawat dengan larutan $\mathrm{NaOH}$ juga mempunyai nilai tertinggi $(\mathrm{p}<0.05), 351.94 \mathrm{mg} / \mathrm{g}$ berbanding $181.44 \mathrm{mg} / \mathrm{g}$ untuk SM mentah dan $183.15 \mathrm{mg} / \mathrm{g}$ untuk SM prarawatan menggunakan larutan $\mathrm{CH}_{3} \mathrm{COOH}$. Jumlah gula penurun per gram subtrat SM prarawatan $(5 \% \mathrm{NaOH})$ dalam kajian ini adalah menghampiri dengan jumlah gula penurun per gram subtrat yang dihasilkan dalam kajian Iberahim et al. (2013) pada keadaan optimum, iaitu hampir $380 \mathrm{mg} / \mathrm{g}$ biojisim kering terhasil selepas prarawatan $6 \% \mathrm{NaOH}$ pada suhu $70{ }^{\circ} \mathrm{C}$ selama 2 jam dalam kebuk tertutup.

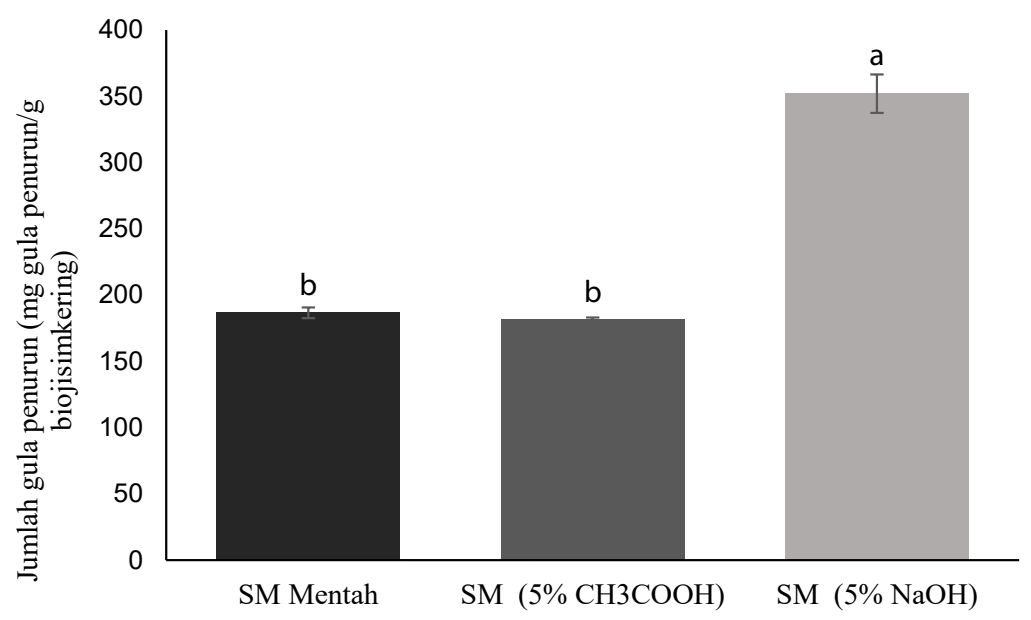

RAJAH 2. Jumlah penghasilan gula penurun dalam proses hidrolisis enzim daripada SM mentah dan prarawatan dengan 5\% (v/v) larutan asid asetik $\left(\mathrm{CH}_{3} \mathrm{COOH}\right)$ dan natrium hidroksida $(\mathrm{NaOH})$ per gram berat kering biojisim $a-b$ : Min dengan huruf yang berbeza adalah berbeza secara signifikan $(p<0.05)$ 
Walau bagaimanapun, kandungan gula penurun SM prarawatan $5 \%(\mathrm{v} / \mathrm{v}) \mathrm{CH}_{3} \mathrm{COOH}$ menunjukkan tiada perbezaan yang ketara dengan SM mentah, iaitu masingmasing pada 16.48 dan $16.3 \%$. Ini menunjukkan bahawa proses prarawatan hidrotermal dengan kehadiran asid lemah (larutan $\mathrm{CH}_{3} \mathrm{COOH}$ ) dalam autoklaf selama 30 min pada suhu $120^{\circ} \mathrm{C}$ adalah kurang berkesan untuk menyingkirkan bahagian lignin dan hemiselulosa SM. Keadaan ini berkemungkinan disebabkan oleh suhu dan tekanan yang digunakan semasa prarawatan dalam autoklaf tidak mencukupi untuk memutuskan ikatan kumpulan asetil antara struktur hemiselulosa. Menurut kajian Wang et al. (2019), pada satu tahap signifikan, $\mathrm{CH}_{3} \mathrm{COOH}$ bertindak memutuskan ikatan kumpulan asetil daripada struktur tulang belakang hemiselulosa semasa proses prarawatan biojisim. Dalam kajian tersebut, mereka mendapati keadaan optimum prarawatan biojisim switchgrass menggunakan larutan $\mathrm{CH}_{3} \mathrm{COOH}$ dalam keluli kalis karat reaktor kelompok adalah pada suhu 170 ${ }^{\circ} \mathrm{C}$ selama $20 \mathrm{~min}$. Wicaksono et al. (2017) menjelaskan penyelidikan menggunakan larutan asid lemah seperti $\mathrm{CH}_{3} \mathrm{COOH}$ yang kurang berkesan, mengakibatkan hasil gula juga berkurang semasa hidrolisis enzim. Oleh yang demikian itu, prarawatan SM dengan larutan alkali (5\% larutan $\mathrm{NaOH}$ ) dalam autoklaf selama 30 min pada suhu $120{ }^{\circ} \mathrm{C}$ lebih berkesan untuk merawat SM berbanding larutan asid lemah $\left(\mathrm{CH}_{3} \mathrm{COOH}\right)$ dengan meningkatkan luas permukaan untuk hidrolisis enzim dan dipilih sebagai prarawatan kajian seterusnya.

\section{KESAN KEPEKATAN LARUTAN NAOH TERHADAP SAKARIFIKASI SM}

Rajah 3 menunjukkan peratusan sakarifikasi hidrolisis enzim bagi SM prarawatan dengan larutan $\mathrm{NaOH}$ pada kepekatan yang berbeza iaitu 5, 10 dan 15\% (v/v). Kesan kepekatan $\mathrm{NaOH}$ yang berbeza dalam prarawatan dinilai dengan membandingkan peratusan sakarifikasi yang dihasilkan selepas proses hidrolisis enzim. Berdasarkan keputusan, peratus sakarifikasi meningkat $(\mathrm{p}<0.05)$ kepada hampir $31 \%$ apabila kepekatan larutan $\mathrm{NaOH}$ ditingkatkan kepada 15\% setelah dirawat selama $30 \mathrm{~min}$, manakala peningkatan 11, 22 dan 25\% dikesan bagi SM mentah, 5 dan $10 \% \mathrm{NaOH} \mathrm{SM}$. Ia dapat diperhatikan bahawa prarawatan dengan $15 \% \mathrm{NaOH}$ pada suhu $120{ }^{\circ} \mathrm{C}$ menghasilkan peratus sakarifikasi yang tertinggi $(\mathrm{p}<0.05)$. Hal ini menunjukkan prarawatan SM dengan kepekatan $15 \% \mathrm{NaOH}$ adalah lebih signifikan $(\mathrm{p}<0.05)$ terhadap SM mentah serta 5 dan $10 \% \mathrm{NaOH}$. Keadaan ini disebabkan oleh berlakunya penyingkiran sebahagian struktur lignin dan hemiselulosa yang lebih tinggi dalam SM prarawatan $(15 \% \mathrm{NaOH})$ berbanding dengan kepekatan lain selepas rawatan (Ali et al. 2015).

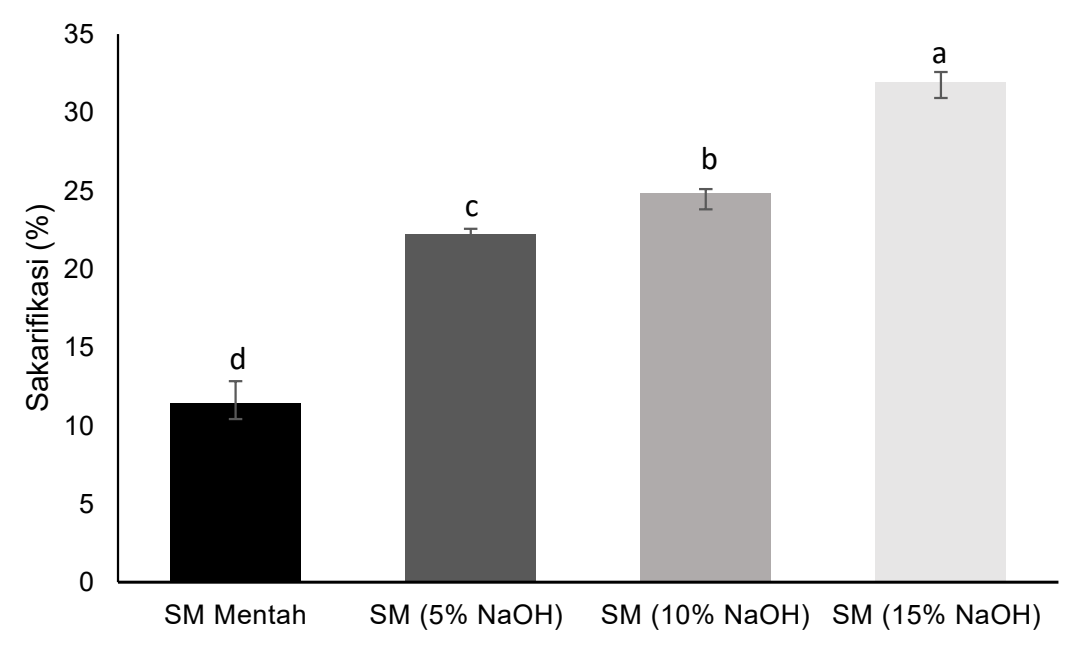

RAJAH 3. Peratusan sakarifikasi bagi SM mentah dan prarawatan alkali dengan kepekatan 5, 10 dan 15\% (v/v) larutan $\mathrm{NaOH}$

a-d: Min dengan huruf yang berbeza adalah berbeza secara signifikan $(\mathrm{p}<0.05)$ 
Tambahan lagi, peningkatan kepekatan larutan $\mathrm{NaOH}$ daripada 5 kepada $15 \%$ dapat meningkatkan lagi proses pembengkakan struktur selulosa hablur selain meningkatkan penyingkiran lignin dan hemiselulosa dan menjurus kepada peningkatan luas permukaan substrat untuk hidrolisis enzim. Kajian terdahulu juga bersetuju bahawa, peningkatan kepekatan larutan alkali dapat meningkatkan keluasan diameter serabut dan meningkatkan pembengkakan serabut selulosa tetapi tidak mendegradasinya secara langsung. Selain itu, peningkatan kepekatan $\mathrm{NaOH}$ memberi kesan yang signifikan terhadap penurunan lignin sebanyak 4 kali ganda (Al-Muraisy et al. 2017; Iberahim et al. 2013; Wicaksono et al. 2017). Penemuan ini sesuai dengan Iberahim et al. (2013) apabila menyatakan kepekatan pelarut adalah merupakan salah satu faktor utama dalam rawatan yang dimanipulasi dalam proses hidrolisis untuk mengekalkan gula karbohidrat dalam substrat yang dirawat. Selain itu, keputusan dalam kajian ini juga adalah selari dengan penemuan dalam kajian Samanta et al. (2015), iaitu penggunaan 16\% $\mathrm{NaOH}$ bersama wap dalam proses prarawatan tongkol jagung mengakibatkan hampir $90 \%$ bahagian hemiselulosa diperoleh bertujuan untuk penghasilan xilo-oligosakarida. Daripada analisis ini dapat disimpulkan, prarawatan SM dengan kepekatan $15 \%(\mathrm{v} / \mathrm{v}) \mathrm{NaOH}$ dapat meningkatkan proses hidrolisis enzim dengan peratus sakarifikasi yang tertinggi iaitu hampir 30\%, iaitu 3 kali ganda berbanding SM mentah.

\section{PENGHASILAN OLIGOSAKARIDA DARIPADA SM PRARAWATAN $15 \% \mathrm{NAOH}$}

Rajah 4 memaparkan kromatogram pemisahan piawai dekstran selepas analisis KCPT pengesan pendafluor dengan unit glukosa (G1 hingga G13), manakala Rajah 5 menunjukkan hasil monosakrida dan oligosakarida bagi SM prarawatan $(15 \% \mathrm{NaOH})$ selepas hidrolisis enzim dengan perbezaan masa. Berdasarkan Rajah 5, secara keseluruhannya, SM prarawatan mengandungi monosakarida dan oligosakarida dengan 2, 3 dan 4 unit glukosa. Keputusan Rajah 5 juga menunjukkan SM prarawatan dengan masa hidrolisis 3 dan 6 jam menghasilkan monosakarida (unit glukosa 1) dan oligosakarida (unit glukosa 2-4) manakala pada masa hidrolisis 0 jam hanya monosakarida (unit glukosa 1) dan disakarida dengan hanya 2 unit glukosa dapat dikesan. Daripada pemerhatian, glukosa (G1), selobiosa (G2), selotriosa (G3) dan selobiosa (G4) adalah oligosakarida yang wujud.

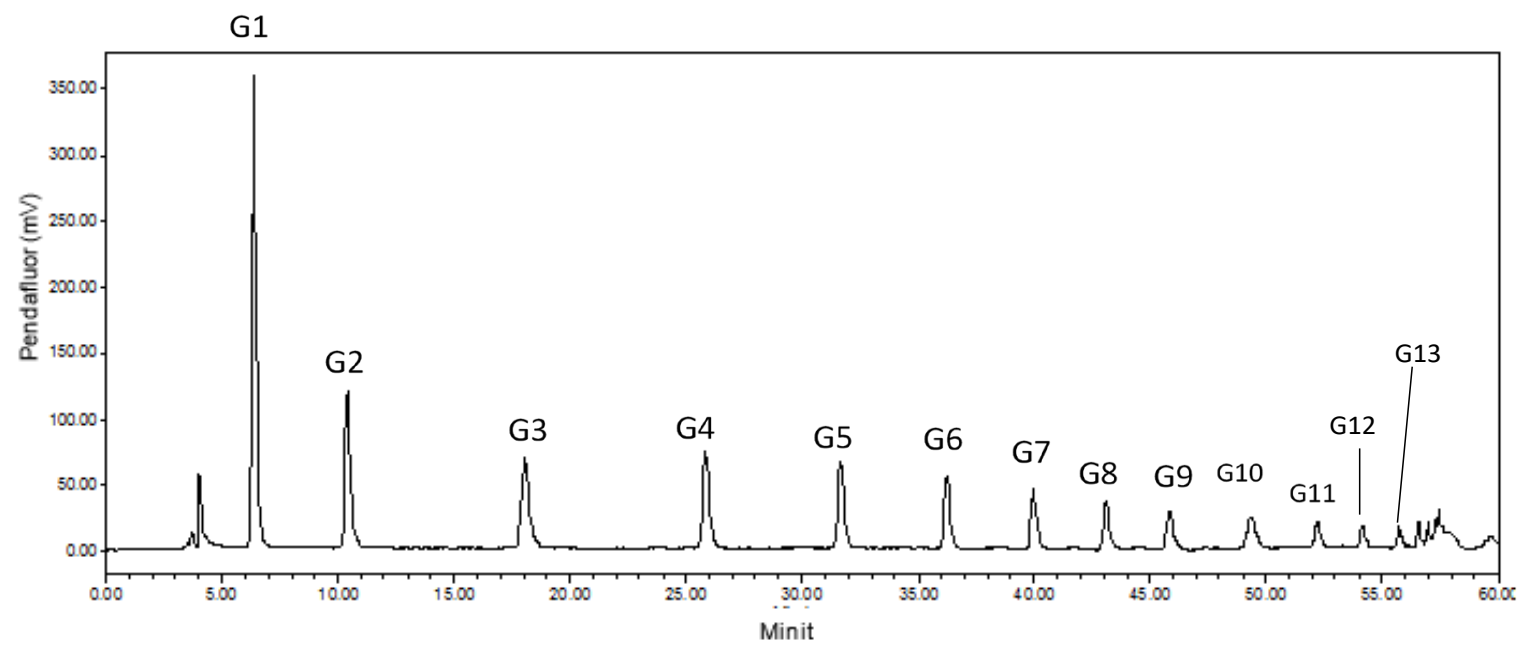

RAJAH 4. Kromatogram pemisahan piawai dekstran menggunakan KCPT pengesan pendafluordengan dengan unit glukosa (G1 hingga G13) 

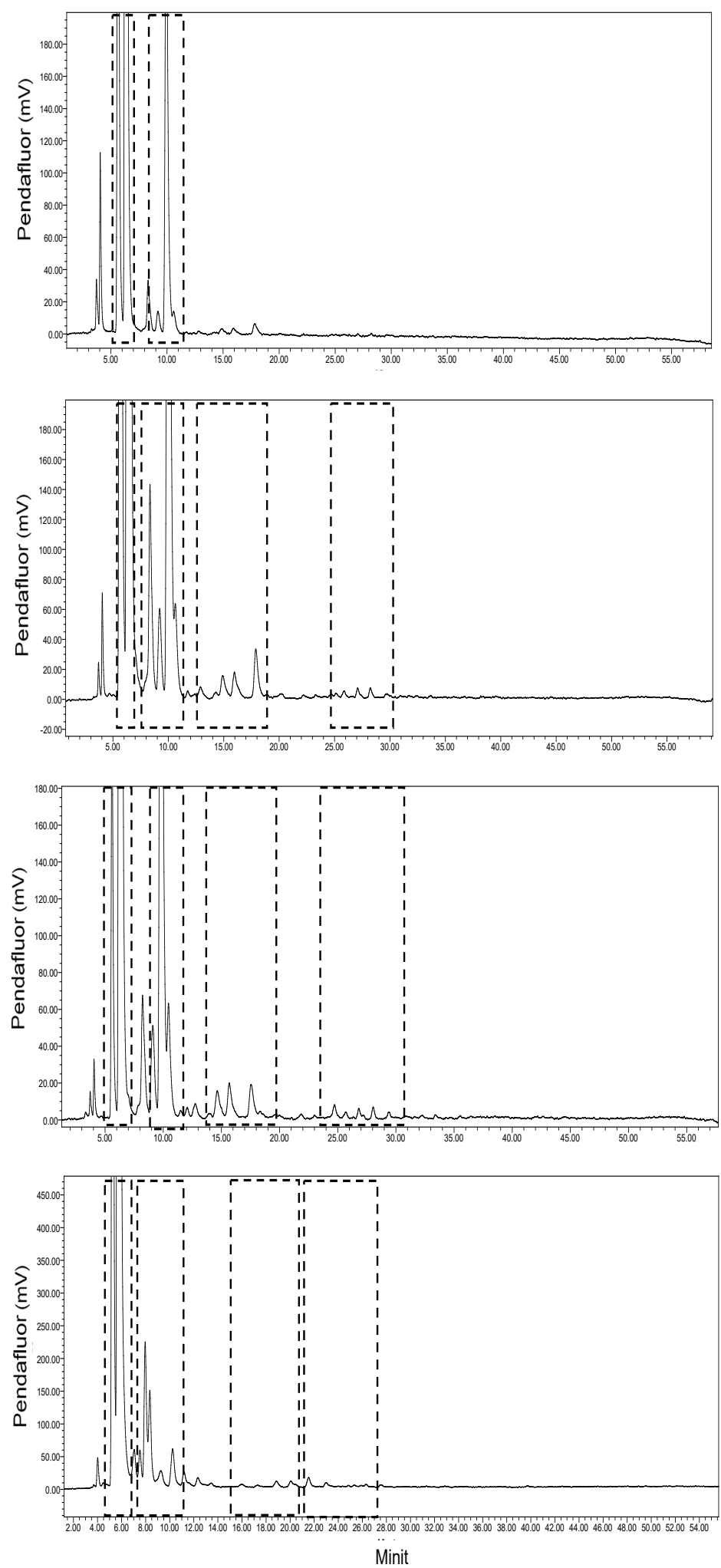

RAJAH 5. Analisis KCPT-pendafluor bagi SM prarawatan $(15 \% \mathrm{NaOH})$ yang dihidrolisis selama (a) 0, (b) 3, (c) 6 dan (d) 24 jam 
Hasil oligosakarida ini adalah sama dengan SM prarawatan yang dihidrolisis selama 24 jam seperti diperhatikan pada Rajah 5. Keputusan ini menunjukkan oligosakarida sehingga 4 unit glukosa sahaja yang terhasil selepas 3 jam dan sehingga 24 jam hidrolisis. Tiada oligosakarida dengan unit glukosa lebih daripada 4 diperoleh. Hal ini kemungkinan kesan aktiviti endoselulase di dalam kompleks enzim Celluclast (1.5 L) yang melalui pemotongan daripada rantai polisakarida kepada oligosakarida selotetraosa (G4), selotriosa (G3), selobiosa (G2) dan selanjutnya pemotongan hujung oligosakarida kepada glukosa oleh $\beta$-glukosidase (QuirozCastañeda \& Folch-Mallol 2013). Enzim komersial Celluclast (1.5 L) daripada Thrichoderma reesei terkenal dengan aktiviti $\beta$-glukosidase (Salleh et al. 2018). Ini mencerminkan proses dinamik hidrolisis oligosakarida dengan saiz besar dipotong seterusnya kepada saiz lebih kecil. Pada akhir analisis, kesemua hasil yang dipotong menjadi sebahagian daripada glukosa dan oligosakarida dengan 2, 3 dan 4 unit glukosa bergantung kepada panjang substrat oligosakarida awal dengan unit tunggal selotriosa akan menghasilkan satu unit selobiosa dan satu unit glukosa, manakala satu unit selotetraosa akan menghasilkan dua unit selobiosa dan satu unit selopentosa akan menghasilkan dua unit selobiosa manakala satu unit glukosa dan seloheksaosa akan menghasilkan tiga unit selobiosa (Woon et al. 2016).

Hasil unit glukosa oligosakarida yang dihasilkan dalam kajian ini adalah menghampiri dengan keputusan oligosakarida dalam kajian Wahlstrom et al. (2012), iaitu kesan hidrolisis mikro hablur selulosa (MCC) menggunakan dua jenis enzim endoglukanase daripada kulat Trichoderma Reesei (Cel7B dan Cel5A) mendapati oligosakarida selobiosa (G2) dan selotriosa (G3) telah dihasilkan selepas hidrolisis enzim selama 2 jam. Tambahan, hasil oligosakarida dalam kajian ini iaitu dengan unit glukosa 2 hingga 4 adalah lebih panjang daripada kajian Karnaouri et al. (2019), apabila oligosakarida dengan selobiosa (G2) dapat diperhatikan hasil tindak balas enzim hidrolisis bahan pokok birch dan kayu cemara sebagai substrat oleh enzim Celluclast (1.5 L) selama 24 jam. Keadaan ini menunjukkan masa hidrolisis selama 3 jam adalah cukup untuk serabut dihidrolisis oleh enzim bagi SM prarawatan dengan $15 \% \mathrm{NaOH}$ dan menghasilkan monosakarida dengan kandungan yang tinggi dan oligosakarida 1 hingga 4 unit glukosa. Oleh yang demikian itu, analisis ini membuktikan masa hidrolisis yang dimanipulasi memberi kesan terhadap penghasilan unit glukosa oligosakarida semasa hidrolisis enzim menggunakan kompleks enzim komersial Celluclast 1.5 L iaitu oligosakarida dengan unit glukosa 1 hingga
4 terhasil daripada SM prarawatan $(15 \% \mathrm{NaOH})$ yang dihidrolisis selama 3 jam.

\section{KESIMPULAN}

Kajian ini menunjukkan bahawa prarawatan hidrotermal dengan kehadiran larutan natrium hidroksida $(\mathrm{NaOH})$ pada suhu $120^{\circ} \mathrm{C}$ yang diautoklaf selama 30 min terbukti dapat meningkatkan jumlah pengeluaran gula dalam proses hidrolisis berbanding dengan larutan asid asetik $\left(\mathrm{CH}_{3} \mathrm{COOH}\right)$. Sementara itu, prarawatan pada kepekatan $15 \%(\mathrm{v} / \mathrm{v})$ larutan $\mathrm{NaOH}$ memberi hasil yang terbaik semasa hidrolisis enzim SM dengan peratus sakarifikasi tertinggi iaitu hampir 31\%, 3 kali ganda berbanding SM mentah. Keputusan juga membuktikan hidrolisis enzim SM prarawatan $(15 \% \mathrm{NaOH})$ menggunakan enzim komersial Celluclast $(1.5 \mathrm{~L})$ berjaya menghasilkan oligosakarida dengan 1 hingga 4 unit glukosa selepas 3 jam hidrolisis.

\section{PENGHARGAAN}

Penulis ingin mengucapkan penghargaan kepada Kementerian Pengajian Tinggi (KPT) melalui Fundamental Research Grant Scheme (FRGS) (FRGS/1/2016/STG03/ UKM/02/6) atas sokongan kewangan sepanjang penyelidikan ini dijalankan.

\section{RUJUKAN}

Aftab, M.N., Iqbal, I., Riaz, F., Karadag, A. \& Tabatabaei, M. 2019. Different pretreatment methods of lignocellulosic biomass for use in biofuel production. Dlm. Biomass for Bioenergy - Recent Trends and Future Challenges, disunting oleh Abomohra, A.E.F. London, United Kingdom: IntechOpen. hlm. 1-24.

Al-Muraisy, S.A.A., Ali, N., Hassan, O. \& Sabeen, A.H. 2017. Alkali pretreatment and acid hydrolysis of oil palm mesocarp fiber (OPMF) to produce glucose. Advanced Science Letters 23(9): 8832-8836.

Ali, N., Aziz, C. \& Hassan, O. 2015. Alkali pretreatment and acid hydrolysis of coconut pulp and empty fruit bunch to produce glucose. Jurnal Teknologi 74(7): 7-11.

Alrumman, S.A. 2016. Enzymatic saccharification and fermentation of cellulosic date palm wastes to glucose and lactic acid. Brazilian Journal of Microbiology 47(1): 110119.

Davila, I., Gullon, B., Alonso, J.L., Labidi, J. \& Gullon, P. 2019 Vine shoots as new source for the manufacture of prebiotic oligosaccharides. Carbohydrate Polymers 207: 34-43.

Dong, M., Wang, S., Xu, F., Wang, J., Yang, N., Li, Q., Chen, J. \& Li, W. 2019. Pretreatment of sweet sorghum straw and its enzymatic digestion: Insight into the structural changes and visualization of hydrolysis process. Biotechnology for Biofuels 12(1): 1-11. 
Gibson, G.R., Hutkins, R., Sanders, M.E., Prescott, S.L., Reimer, R.A., Salminen, S.J., Scott, K., Stanton, C., Swanson, K.S., Cani, P.D., Verbeke, K. \& Reid, G. 2017. Expert consensus document: The International Scientific Association for Probiotics and Prebiotics (ISAPP) consensus statement on the definition and scope of prebiotics. Nature Reviews Gastroenterology \& Hepatology 14(8): 491-502.

Ghose, T. 1987. Measurement of cellulase activities. Pure and Applied Chemistry 59(2): 257-268.

Hassan, O., Ling, T.P., Maskat, M.Y., Illias, R.M., Badri, K., Jahim, J. \& Mahadi, N.M. 2013. Optimization of pretreatments for the hydrolysis of oil palm empty fruit bunch fiber (EFBF) using enzyme mixtures. Biomass \& Bioenergy 56: 137-146.

Hustoft, T.N., Hausken, T., Ystad, S.O., Valeur, J., Brokstad, K., Hatlebakk, J.G. \& Lied, G.A. 2016. Effects of varying dietary content of fermentable short-chain carbohydrates on symptoms, fecal microenvironment, and cytokine profiles in patients with irritable bowel syndrome. Neurogastroenterology \& Motility 29(4): 1-9.

Ioelovich, M. \& Morag, E. 2012. Study of enzymatic hydrolysis of mild pretreated lignocellulosic biomasses. BioResources 7(1): 1040-1052.

Iberahim, N.I., Jahim, J.M., Harun, S., Nor, M.T.M. \& Hassan, O. 2013. Sodium hydroxide pretreatment and enzymatic hydrolysis of oil palm mesocarp fiber. International Journal of Chemical Engineering and Applications 4(3): 101-105.

Jalaludin, I., Sudin, A.H., Said, I.M., Azizan, K.A., Baharum, S.N., Murad, A.M.A., Bakar, F.D.A., Mahadi, N.M., Wormald, M.R. \& Alonzi, D.S. 2017. Fluorescence and evaporative light scattering HPLC profiling of intracellular asparagine $(\mathrm{N})$ linked oligosaccharides from Saccharomyces cerevisiae using the alg8 mutant. Malaysian Journal of Analytical Sciences 21(6): 1210-1218.

Jahromi, M.F., Liang, J.B., Abdullah, N., Goh, Y.M., Ebrahimi, R. \& Shokryazdan, P. 2016. Extraction and characterization of oligosaccharides from palm kernel cake as prebiotic. BioResources 11(1): 674-695.

Kalidas, N.R., Saminathan, M., Ismail, I.S., Abas, F., Maity, P., Islam, S.S., Manshoor, N. \& Shaari, K. 2017. Structural characterization and evaluation of prebiotic activity of oil palm kernel cake mannanoligosaccharides. Food Chemistry 234: 348-355.

Karnaouri, A., Matsakas, L., Bühler, S., Muraleedharan, M.N., Christakopoulos, P. \& Rova, U. 2019. Tailoring Celluclast ${ }^{\mathbb{B}}$ cocktail's performance towards the production of prebiotic cello-oligosaccharides from waste forest biomass. Catalysts 9(11): 897-913.

Kumar, A.K. \& Sharma, S. 2017. Recent updates on different methods of pretreatment of lignocellulosic feedstocks: A review. Bioresources and Bioprocessing 4(1): 7-26.

Liang, S., Liao, W., Ma, X., Li, X. \& Wang, Y. 2017. $\mathrm{H}_{2} \mathrm{O}_{2}$ oxidative preparation, characterization and antiradical activity of a novel oligosaccharide derived from flaxseed gum. Food Chemistry 230: 135-144.
Mandels, M. \& Sternberg, D. 1976. Recent advances in cellulase technology. Journal of Fermentation Technology 54(4): 267-286.

Modenbach, A.A. \& Nokes, S. E. 2012. The use of high-solids loadings in biomass pretreatment - A review. Biotechnology and Bioengineering 109(6): 1430-1442.

Modenbach, A.A. \& Nokes, S.E. 2014. Effects of sodium hydroxide pretreatment on structural components of biomass. Transactions of the ASABE 57(4): 1187-1198.

Moller, M.S., Goh, Y.J., Viborg, A.H., Andersen, J.M., Klaenhammer, T.R., Svensson, B. \& Hachem, M.A. 2014. Recent insight in $\alpha$-glucan metabolism in probiotic bacteria. Biologia 69(6): 713-721.

Nurhayati, Hartutik, Sjofjan, O. \& Widodo, E. 2018. Production of mannan oligosaccharides (MOS) extracted from fermented palm kernel cake and cassava by-product mixture and its efficacy as prebiotic. Livestock Research for Rural Development 30(10): 1-8.

Pasma, S.A., Daik, R. \& Maskat, M.Y. 2018. Enzymatic synthesis of biodegradable polyesters using succinic acid monomer derived from cellulose of oil palm empty fruit bunch. Journal of Wood Chemistry and Technology 38(6): 445-459.

Pasma, S.A., Daik, R., Maskat, M.Y. \& Hassan, O. 2013. Application of Box-Behnken design in optimization of glucose production from oil palm empty fruit bunch cellulose. International Journal of Polymer Science 2013: 1-8.

Pasma, S.A., Daik, R., Ramli, S., Maskat, M.Y. \& Zulfakar, M.H. 2019. Enzymatic degradation of lignin extracted from oil palm empty fruit bunch using laccase and cutinase. BioResources 14(4): 8879-8891.

Peerakietkhajorn, S., Jeanmard, N., Chuenpanitkit, P., K-Da, S., Bannob, K. \& Khuituan, P. 2020. Effects of plant oligosaccharides derived from dragon fruit on gut microbiota in proximal and distal colon of mice. Sains Malaysiana 49(3): 603-611.

Quiroz-Castañeda, R.E. \& Folch-Mallol, J.L. 2013. Hydrolysis of biomass mediated by cellulases for the production of sugars. Dlm. Sustainable Degradation of Lignocellulosic Biomass Techniques, Applications and Commercialization, edited by Chandel, A. \& Da Silva, S.S. London, United Kingdom: IntechOpen. pp. 119-155.

Ren, Z., Wang, C., Zuo, Q., Yousfani, S.H.S., Anuar, N.S., Zakaria, S. \& Liu, X. 2019. Effect of alkali treatment on interfacial and mechanical properties of kenaf fibre reinforced epoxy unidirectional composites. Sains Malaysiana 49(3): 173-181.

Saha, S., Kurade, M.B., El-Dalatony, M.M., Chatterjee, P.K., Lee, D.S. \& Jeon, B.H. 2016. Improving bioavailability of fruit wastes using organic acid: An exploratory study of biomass pretreatment for fermentation. Energy Conversion and Management 127: 256-264.

Salleh, N.S., Bakar, F.D.A. \& Murad, A.M.A. 2018. Effect of Humicola insolens recombinant endoglucanase on the performance of commercial cellulase in oil palm biomass hydrolysis. Malaysian Journal of Microbiology 14(6): 547553. 
Samanta, A.K., Jayapal, N., Kolte, A.P., Senani, S., Sridhar, M., Dhali, A., Suresh, K.P., Jayaram, C. \& Prasad, C.S. 2015. Process for enzymatic production of xylooligosaccharides from the xylan of corn cobs. Journal of Food Processing and Preservation 39(6): 729-736.

Wahlström, R., Rovio, S. \& Suurnäkki, A. 2012. Partial enzymatic hydrolysis of microcrystalline cellulose in ionic liquids by Trichoderma reesei endoglucanases. RSC Advances 2(10): 4472-4480.

Warid, W.N.M., Ariffin, H., Hassan, M.A. \& Shirai, Y. 2016. Optimization of superheated steam treatment to improve surface modification of oil palm biomass fiber. BioResources 11(3): 5780-5796.

Wicaksono, A., Rahmawan, A., Matin, H.H.A., Wardani, L.G.K., Kusworo, T.D. \& Sumardiono, S. 2017. The effect of pretreatment using sodium hydroxide and acetic acid to biogas production from rice straw waste. MATEC Web of Conferences 101, 02011. United Kingdom: EDP Sciences. hlm. 1-6.

Wilson, B. \& Whelan, K. 2017. Prebiotic inulin-type fructans and galacto-oligosaccharides: Definition, specificity, function and application in gastrointestinal disorders. Journal of Gastroenterology and Hepatology 32(S1): 64-68.

Woon, J.S.K., Mackeen, M.M., Bin Sudin, A.H., Mahadi, N.M., Illias, R.M., Murad, A.M.A. \& Bakar, F.D.A. 2016. Production of an oligosaccharide-specific cellobiohydrolase from the thermophilic fungus Thielavia terrestris. Biotechnology Letters 38(5): 825-832.

Wu, H., Dai, X., Zhou, S.L., Gan, Y.Y., Xiong, Z.Y., Qin, Y.H., Ma, J., Yang, L., Wu, Z.K., Wang, T.L. \& Wang, W.G. 2017. Ultrasound-assisted alkaline pretreatment for enhancing the enzymatic hydrolysis of rice straw by using the heat energy dissipated from ultrasonication. Bioresource Technology 241: $70-74$.
Zakaria, M.R., Hirata, S. \& Hassan, M.A. 2014. Combined pretreatment using alkaline hydrothermal and ball milling to enhance enzymatic hydrolysis of oil palm mesocarp fiber. Bioresource Technology 169: 236-243.

Zhang, S., Hu, H., Wang, L., Liu, F. \& Pan, S. 2018. Preparation and prebiotic potential of pectin oligosaccharides obtained from citrus peel pectin. Food Chemistry 244: 232-237.

Nurul Hanisah Mohd, Rizafizah Othaman \& Mukram Mohamed Mackeen

Jabatan Sains Kimia

Fakulti Sains dan Teknologi

Universiti Kebangsaan Malaysia

43600 UKM Bangi, Selangor Darul Ehsan

Malaysia

Mohamad Yusof Maskat*

Jabatan Sains Makanan

Fakulti Sains dan Teknologi

Universiti Kebangsaan Malaysia

43600 UKM Bangi, Selangor Darul Ehsan

Malaysia

Mukram Mohamed Mackeen

Institut Biologi Sistem (INBIOSIS)

Universiti Kebangsaan Malaysia

43600 UKM Bangi, Selangor Darul Ehsan

Malaysia

*Pengarang untuk surat-menyurat; email: yusofm@ukm.edu.my

Diserahkan: 21 Mei 2020

Diterima: 31 Oktober 2020 